\title{
Comparison of Panoramic Radiography and Cone-Beam Computed Tomography for the Detection of Tonsilloliths
}

\author{
Melih Ozdede $^{a}$ Gulsun Akay ${ }^{b}$ Ozge Karadag ${ }^{c}$ Ilkay Peker ${ }^{b}$ \\ ${ }^{a}$ Department of Dentomaxillofacial Radiology, Faculty of Dentistry, Pamukkale University, Denizli, Turkey; \\ ${ }^{b}$ Department of Dentomaxillofacial Radiology, Faculty of Dentistry, Gazi University, Ankara, Turkey; \\ 'Department of Statistics, Faculty of Science, Hacettepe University, Ankara, Turkey
}

\section{Significance of the Study}

- The aim of this study was to compare cone-beam computed tomography (CBCT) and panoramic radiography $(\mathrm{PR})$ for the detection of tonsilloliths.

- The detection rate of tonsilloliths was $33.2 \%$ on CBCT.

- Only $51.4 \%$ of the tonsilloliths detected on CBCT were identified by PR.

- PR was not adequate to detect tonsilloliths $1 \mathrm{~mm}$ or smaller in size.

\section{Keywords}

Cone-beam computed tomography · Otolaryngology •

Diagnostic imaging · Radiography · Palatine tonsil ·

Calcinoses $\cdot$ Halitosis

\begin{abstract}
Objective: A tonsillolith is a concretion of the tonsillar crypt. The aim of this retrospective study was to compare panoramic radiography (PR) and cone-beam computed tomography $(\mathrm{CBCT})$ for the detection of tonsilloliths. Materials and Methods: The CBCT images of 527 patients with maxillofacial volume were evaluated retrospectively. Of these, $175 \mathrm{pa}-$ tients (81 females, 94 males; mean age 51.05 years) had unilateral or bilateral tonsilloliths. In total, 151 of them (67 females, 84 males; mean age, 51.03 years) had PR images performed in the same period and were included in the study. The PR images were examined to ascertain whether
\end{abstract}

known tonsilloliths (from CBCT images) could be detected. The location (unilateral; left or right and bilateral), size, and number of the tonsilloliths were examined on both CBCT and PR images. Descriptive analysis, Spearman's rho correlation coefficient, and $x^{2}$ tests were used for the statistical analysis. Results: The detection rate of tonsillolith was $33.2 \%$ on CBCT images. Only $51.4 \%$ of the tonsilloliths detected on CBCT were evaluated by PR; the correlation between CBCT and PR was found to be significant (Spearman's $r=0.399$, $p=0.000$ ). PR was not adequate to detect tonsilloliths $1 \mathrm{~mm}$ or smaller in size. All the calcifications larger than $5 \mathrm{~mm}$ were detected on PR images. Conclusion: The results of this study showed that more than half of the tonsilloliths observed in CBCT were also detected in PR. Tonsilloliths larger than $2 \mathrm{~mm}$ were more likely to be detected on PR images.

C 2019 The Author(s)

Published by S. Karger AG, Basel

\begin{tabular}{|c|c|c|}
\hline KARGER & $\begin{array}{l}\text { () } 2019 \text { The Author(s) } \\
\text { Published by S. Karger AG, Basel }\end{array}$ & $\begin{array}{l}\text { Karger } \\
\text { Open access }\end{array}$ \\
\hline $\begin{array}{l}\text { karger@karger.com } \\
\text { www.karger.com/mpp }\end{array}$ & $\begin{array}{l}\text { This is an Open Access article licensed } \\
\text { Attribution-NonCommercial- } 4.0 \text { Intern } \\
\text { (thttp///www.karger.com/Services/Open } \\
\text { the online version of the article only. Usa } \\
\text { mercial purposes requires written perm }\end{array}$ & $\begin{array}{l}\text { r the Creative Commons } \\
\text { nal License (CC BY-NC) } \\
\text { essLicense), applicable to } \\
\text { ind distribution for com- } \\
\text { n. }\end{array}$ \\
\hline
\end{tabular}

Melih Ozdede

Department of Dentomaxillofacial Radiology

Faculty of Dentistry, Pamukkale University

Kinikli Campus, TR-20160 Denizli (Turkey)

melihozdede@gmail.com 


\section{Introduction}

A tonsillolith is a calcified structure that occurs as a result of chronic and recurrent inflammation in enlarged tonsillar crypts. On clinical examination, tonsilloliths are generally seen as white or yellow plaques in the tonsil crypts, especially in palatine tonsils. Tonsilloliths can be as hard as stone when they have been present for a long time. Smallsized tonsilloliths are usually asymptomatic, but large ones may present several symptoms such as irritation, pain, discomfort and foreign body sensation, swallowing and eating difficulties, bad breath, bad taste, ear pain, and ulceration $[1,2]$. Palatine tonsilloliths may cause orofacial pain and glossopharyngeal neuralgia [3]. They may be single or multiple and unilateral or bilateral [4]. The size of the lesions may vary from a few millimeters to several centimeters [5].

The differential diagnosis of tonsilloliths can be made by various lesions in the mandibular ramus region, such as odontoma, osteoma, idiopathic osteosclerosis, sialolithiasis, phlebolith, cysticercosis, calcified lymph nodes, carotid calcification, long hamular process, stylohyoid ligament calcification, or osteoma cutis and foreign body $[2,3,6]$. Tonsilloliths can be detected by routine panoramic radiographic images [5].

Panoramic radiography $(\mathrm{PR})$ is a technique that allows the viewing of the maxilla, mandible, and facial structures in a single image. This radiographic technique lets us examine fractures, pathologies, developmental anomalies, development of the teeth, temporomandibular joint, maxillary sinuses, and so on. Whether a lesion is in soft or hard tissue is indistinguishable on PR images. In these cases, posteroanterior skull radiographs or reverse Towne projections may be useful. Tonsilloliths appear as single or multiple radiopacities that overlap the mid-portion of the mandibular ramus on PR images [1].

Recently, 3-dimensional imaging by cone-beam computed tomography (CBCT) has been recommended for the imaging of tonsilloliths [2]. CBCT images allow us to examine a 3-dimensional image of the maxillofacial region [1]. Palatine tonsilloliths can be detected with CBCT as small radiopacities in the medial part of the ramus mandible and the lateral wall of the oropharyngeal airway. The density of these calcifications is similar to cortical bone $[1,2]$.

The aim of this retrospective study was to compare CBCT and PR images for the detection of tonsilloliths. We hypothesized that the detectability of tonsilloliths in PR would be lower than that in CBCT. Our null hypothesis was that the detection rate of tonsilloliths would be similar in PR and CBCT images.

\section{Materials and Methods}

A priori power analysis with a significance level of $5 \%$ and an effect size of 0.30 indicated that the minimum number of patients required was 150 . Inclusion criteria were patients aged over 18 years old who had both face-scanned (field of view $20 \times 17 \mathrm{~cm}$ ) $\mathrm{CBCT}$ and PR images in the radiology records. The exclusion criteria were the presence of prominent artifacts on CBCT and PR images, pediatric patients, and individuals who had maxillofacial trauma. For this cross-sectional descriptive study, we examined CBCT images in the records of our radiology department between January 2018 and March 2019. Next, CBCT images with tonsilloliths were selected. Finally, the images of the patients who had both $\mathrm{CBCT}$ and PR records (simultaneously) were included in the study.

The CBCT images were obtained by a standing patient positioning device (Promax 3D Mid; Planmeca Oy, Helsinki, Finland). The exposure parameters were $90 \mathrm{kVp}, 12 \mathrm{~mA}$, and the total scanning time was $27.7 \mathrm{~s}$, with a $0.4-\mathrm{mm}$ voxel size. In the axial sections, the radiopaque calcifications were scanned between the medial part of the mandibular ramus and the lateral wall of the oropharyngeal airway. The lesions were confirmed in sagittal and coronal planes. Evaluations were made with the original software program of the CBCT device (Romexis 2.7.0; Planmeca Oy).

The PR images were obtained by a digital panoramic X-ray unit (Orthophos XG-5; Sirona, Bensheim, Germany), operating at 66 $\mathrm{kVp}, 8 \mathrm{~mA}$, with $14 \mathrm{~s}$ of exposure time, a $0.5-\mathrm{mm}$ focal spot, and a magnification ratio of 1.25 . Radiologically visible radiopacities in the mid-portion of the mandibular ramus region were evaluated as a tonsillolith by the radiologists. All radiographic evaluations were made on a 24 -inch Philips medical monitor with a NVDIA Quadro FX 380 graphics card and 1,920 × 1,080-pixel resolution.

All blinded images were retrospectively evaluated by consensus of 2 experienced dentomaxillofacial radiologists (M.O. and G.A.), in a quiet room with subdued ambient lighting and sufficient distance from the screen. The PR images were examined for the presence of tonsilloliths, location (left, right, or bilateral), size, and number of the lesions. Both CBCT and PR images were compared regarding the detection of tonsilloliths and their symmetry, size, and number.

The data obtained were statistically analyzed by non-parametric correlation methods, using SPSS version 23.0 (IBM, Armonk, NY, USA). Statistical analysis was performed using descriptive statistics, Spearman's rho correlation coefficient, and the $\chi^{2}$ test. The significance level was set to 0.05 . Examples of tonsilloliths on both CBCT and PR images are shown in Figures 1 and 2.

\section{Results}

CBCT images of 527 patients were examined retrospectively, and tonsilloliths were determined on $175 \mathrm{im}$ ages (33.2\%). Then, 151 patients with both CBCT and PR images were identified. At least 1 tonsillolith was observed on 96 PR images. The relationship between gender and the detection rates of tonsilloliths was analyzed by $\chi^{2}$ test. Tonsilloliths were found in 84 males (55.6\%) and in 

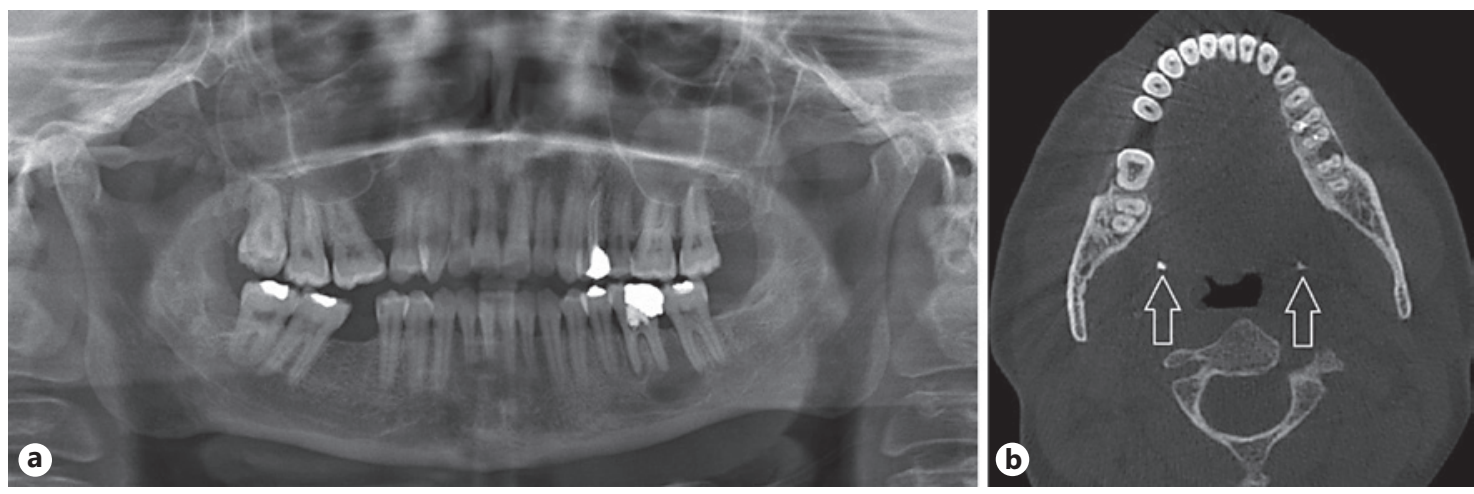

Fig. 1. Bilateral tonsilloliths are not visible on the PR image (a), while they are seen (arrows) on the axial section of the CBCT image (b).
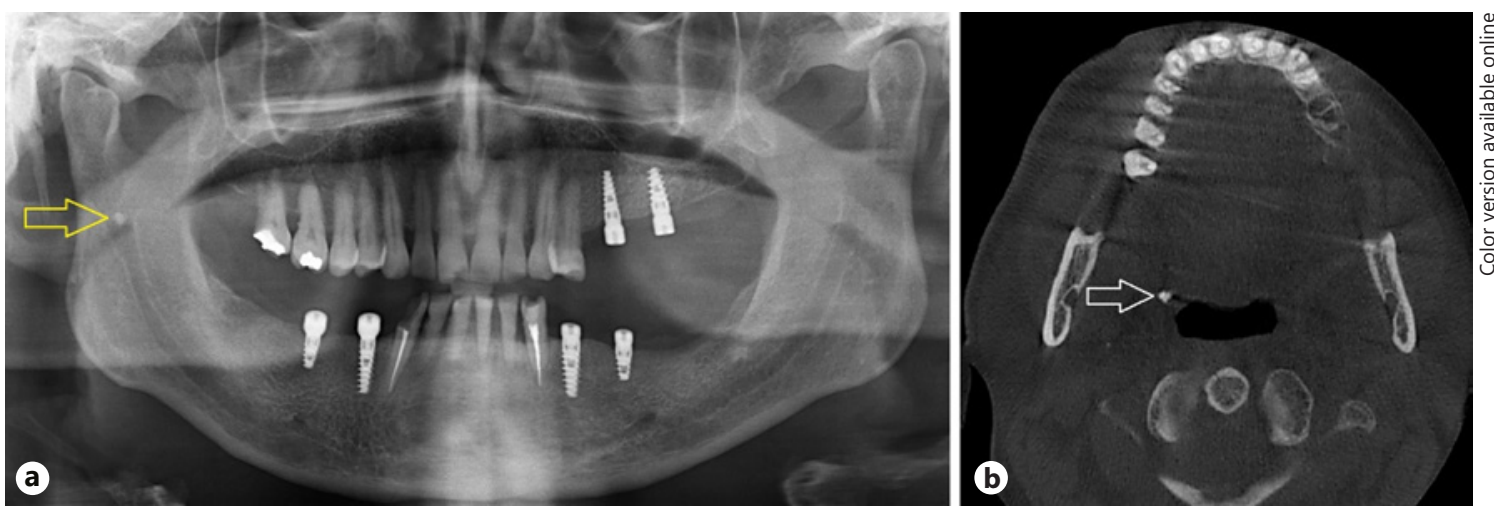

Fig. 2. A right tonsillolith (arrow) is visible on the PR image (a) and on the axial section of the CBCT image (b).

Table 1. Distribution of tonsilloliths by age group

\begin{tabular}{llllllll}
\hline \multicolumn{9}{c}{ Age group } & \multicolumn{2}{c}{} & \multirow{2}{*}{$p$ value } \\
\cline { 2 - 6 } & $\begin{array}{l}18-24 \\
\text { years }\end{array}$ & $\begin{array}{l}25-34 \\
\text { years }\end{array}$ & $\begin{array}{l}35-44 \\
\text { years }\end{array}$ & $\begin{array}{l}45-54 \\
\text { years }\end{array}$ & $\begin{array}{l}55-64 \\
\text { years }\end{array}$ & $\begin{array}{l}65-80 \\
\text { years }\end{array}$ & \\
\hline $\mathrm{CBCT}, n(\%)$ & $13(8.6)$ & $7(4.6)$ & $22(14.6)$ & $39(25.8)$ & $50(33.1)$ & $20(13.2)$ & 0.736 \\
$\mathrm{PR}, n(\%)$ & $6(6.3)$ & $5(5.2)$ & $10(10.4)$ & $26(27.1)$ & $35(36.5)$ & $14(14.6)$ & 0.613 \\
\hline
\end{tabular}

67 females $(44.4 \%)$ on CBCT images $(p=0.923)$. On PR images, these calcifications were observed in 55 males $(57.3 \%)$ and in 41 females $(42.7 \%$; $p=0.572)$.

The mean age for females was $51.52 \pm 12.71$ years, and for males it was $50.64 \pm 14.46$ years. The minimum and maximum ages for females were 21 and 80 years, respectively, whereas the ages ranged between 18 and 77 years for males. The overall mean age was $51.03 \pm 13.67$ years. The tonsilloliths were commonly observed in patients

PR versus CBCT for the Detection of Tonsilloliths who were between 55 and 64 years of age, while fewer patients between 25 and 34 years showed evidence of tonsilloliths on both CBCT and PR images. According to the results of the $\chi^{2}$ test, there were no statistically significant differences between age groups in CBCT $(p=0.736)$ and PR $(p=0.680)$. The detailed distribution of tonsilloliths according to age groups is shown in Table 1.

The most common location of tonsilloliths were the right side (39.7\%), bilateral (37.7\%), and left side (22.5\%) 
Table 2. Correlation between CBCT and PR in the detection of tonsilloliths

\begin{tabular}{|c|c|c|c|c|c|}
\hline & \multicolumn{2}{|l|}{$\mathrm{PR}, n(\%)$} & \multirow{2}{*}{$\begin{array}{l}\text { Total, } \\
n\end{array}$} & \multirow{2}{*}{$\begin{array}{l}\text { Spearman's rho } \\
\text { correlation coefficient }\end{array}$} & \multirow[t]{2}{*}{$p$ value } \\
\hline & not detected & detected & & & \\
\hline CBCT & & & & 0.399 & $0.000^{*}$ \\
\hline Not detected & $85(90.4)$ & $9(9.6)$ & 94 & & \\
\hline Detected & $101(48.6)$ & $107(51.4)$ & 208 & & \\
\hline Total, $n$ & 186 & 116 & 302 & & \\
\hline
\end{tabular}

* Significant at 0.05. In total, 302 sides were analysed in 151 patients.

Table 3. Sizes of the tonsilloliths on CBCT and PR and detection rate via PR (multiple lesions were classified separately)

\begin{tabular}{lllll}
\hline $\begin{array}{l}\text { Size, } \\
\mathrm{mm}\end{array}$ & $\begin{array}{l}\text { CBCT, } \\
n(\%)\end{array}$ & $\begin{array}{l}\text { PR, } \\
n(\%)\end{array}$ & $\begin{array}{l}\text { Detection } \\
\text { rate } \\
\text { via PR }\end{array}$ & $\begin{array}{l}\text { Pearson's } \chi^{2} \\
\text { asymptotic } \\
\text { significance } \\
\text { (2-sided) }\end{array}$ \\
\hline$<1$ & $176(39.8)$ & $16(9.3)$ & 9.1 & \\
1 & $70(15.8)$ & $20(11.6)$ & 28.6 & \\
2 & $101(22.9)$ & $59(34.1)$ & 58.4 & \\
3 & $58(13.1)$ & $45(26.0)$ & 77.6 & $0.000^{*}$ \\
4 & $22(5.0)$ & $18(10.4)$ & 81.8 & \\
5 & $9(2.0)$ & $9(5.2)$ & 100.0 & \\
6 & $4(0.9)$ & $4(2.3)$ & 100.0 & \\
7 & $2(0.5)$ & $2(1.2)$ & 100.0 & \\
\hline Total & $442(100)$ & $173(100)$ & 39.1 & \\
\hline
\end{tabular}

* Significant at 0.05 .

in CBCT. Using PR, tonsilloliths were detected on the right side (52.1\%), left side (27.1\%), and bilaterally (20.8\%).

The correlation between CBCT and PR in the detection of tonsilloliths was analyzed by Spearman's rho correlation coefficient (Table 2). A statistically significant moderate relationship was found between CBCT and PR $(p=0.000)$ and the value of correlation was found to be moderate, approximately $0.40(p=0.000)$. The detection rate of tonsilloliths by PR was found to be $51.4 \%$.

The sizes of tonsilloliths on CBCT and PR images, and detection rate by $\mathrm{PR}$, are stated in Table 3. In the results for $\mathrm{CBCT}$, more than half of the detected lesions were $1 \mathrm{~mm}$ or smaller in size. On PR, $34.1 \%$ of the tonsilloliths were $2 \mathrm{~mm}$ in size, and $26.0 \%$ were $3 \mathrm{~mm}$ in size. The $\chi^{2}$ test was used to compare the different levels of sizes, and the levels were reorganized to combine the largest tonsilloliths sized between 5 and $7 \mathrm{~mm}$ into one
Table 4. Number of the tonsilloliths by CBCT and PR and detection rate via $\mathrm{PR}$

\begin{tabular}{lllll}
\hline$n$ & $\begin{array}{l}\text { CBCT, } \\
n(\%)\end{array}$ & $\begin{array}{l}\text { PR, } \\
n(\%)\end{array}$ & $\begin{array}{l}\text { Detection } \\
\text { rate } \\
\text { via PR, \% }\end{array}$ & $\begin{array}{l}\text { Pearson's } \chi^{2} \\
\text { asymptotic } \\
\text { significance } \\
\text { (2-sided) }\end{array}$ \\
\hline 1 & $106(51.0)$ & $88(75.9)$ & 83.0 & \\
2 & $33(15.9)$ & $14(12.1)$ & 42.4 & \\
3 & $38(18.3)$ & $9(7.8)$ & 23.7 & $0.000^{*}$ \\
4 & $17(8.2)$ & $2(1.7)$ & 11.8 & \\
5 & $4(1.9)$ & $2(1.7)$ & 50.0 & \\
6 & $4(1.9)$ & 0 & 0 & \\
7 & $5(2.4)$ & $1(0.9)$ & 20.0 & \\
8 & $1(0.5)$ & 0 & 0 & \\
\hline Total & $208(100.0)$ & $116(100.0)$ & 55.8 & \\
\hline
\end{tabular}

* Significant at 0.05 .

category. A significant difference was detected between 6 different levels of sizes $(p=0.000)$. Tonsilloliths $2 \mathrm{~mm}$ and larger were found to be more detectable on PR, and the detection rate of 2-mm lesions was approximately $60 \%$. The detectability of tonsilloliths sized $3 \mathrm{~mm}$ and larger were found to be statistically the same using both methods. The correlation between size and detectability of PR analyzed by the gamma correlation coefficient and according to the value of $0.794(p=0.000)$, size, and detectability using PR were found to be highly correlated.

Table 4 shows the number of tonsilloliths on CBCT and $\mathrm{PR}$ images and detectability by $\mathrm{PR}$. The detection rate of single tonsilloliths was high in both imaging techniques, $51.0 \%$ for CBCT and $75.9 \%$ for PR. The number of tonsilloliths detected by CBCT and the number of tonsilloliths detected by PR were strongly correlated to each other $(r=0.68 ; p=0.000)$. 


\section{Discussion}

The detection of tonsilloliths is important for patients. Clinically, these calcifications may be associated with halitosis, odynophagia, otalgia, and upper airway obstruction. Symptomatic or larger tonsillar calcifications should be removed [1,7-11].

Tonsilloliths may be incidentally identified by PR, but they may not be diagnosed because of some disadvantages, such as superimpositions, distortion, and magnification $[1,3,8]$. These calcifications are easily observed with 3-dimensional images and distinguished from other soft tissue calcifications $[8,12]$. The accurate radiographic diagnosis of palatine tonsilloliths can be made by medical CT between the palatopharyngeus and palatoglossus muscles [6, 13]. However, CBCT uses a significantly smaller radiation dose, slices images more thinly, and is less expensive compared to CT $[13,14]$. Although CBCT has limited soft tissue imaging capacity, tonsilloliths can be determined on 3-dimensional CBCT images [15-17]. Ultrasonography can also be used for the detection of soft tissue calcifications [18]. In the literature, it was reported that tonsilloliths could be diagnosed by an intraoral transducer [19]. Ultrasonography has some limitations, such as patient discomfort and difficulty of use [19].

In the literature, the prevalence of tonsilloliths was evaluated using PR, CT, and CBCT. The prevalence of tonsilloliths in PR was found to be $5.7-13 \%$ in previous studies $[4,6,20,21]$. Retrospective 3 -dimensional radiographic studies showed that the prevalence of tonsilloliths was found to be $16-46 \%$ by CT $[3,7,8,12,22-24]$ and $5-34 \%$ by CBCT $[15,17,25-27]$. These differences may be due to differences in the demographics of the patients in these studies [3]. In addition, results may vary according to health conditions, such as poor oral hygiene and smoking habits of examined individuals [12]. The higher rate of tonsilloliths in our study may be associated with a larger field of view compared with other CBCT studies [25-27].

No significant difference between genders was reported in the previous studies $[6,7,16,20,23,28,29]$. The rate of tonsilloliths in males was found to be $41-51.2 \%$ in CT studies $[3,7,8,12], 41-50.5 \%$ in CBCT studies [15-17], and $50.9-60.4 \%$ in PR studies $[3,20,30]$. The results of our study for both imaging techniques were in accordance with previous studies. Tonsilloliths may be identified at any age, and they are most frequently seen between the age of 40 and 50 years [20,28,29]. Likewise, in our study, more than half of the lesions were detected in patients between 45 and 64 years of age. This result was

PR versus CBCT for the Detection of Tonsilloliths comparable with previous studies [6, 20]. Oda et al. [7] reported that as patients aged, the detection rate increased. Otherwise, similar to our study, Fauroux et al. [23] stated that no correlation was found between age and the prevalence of tonsilloliths. Previous studies reported that unilateral tonsilloliths were more common than bilateral tonsilloliths, and no significant differences were found between the prevalence of calcifications in the right and left side $[7,12]$. Our results were similar to the rates reported by other authors.

Two previous studies have reported the detection rate of tonsilloliths by PR and CT [3, 7]. Oda et al. [7] reported that the detection rate of tonsilloliths was $46.1-7.7 \%$ on CT and PR images, respectively. Thus, only one sixth of the calcifications were detected by PR according to that study [7]. The authors emphasized that the main causes for the discrepancy between the 2 imaging techniques were the calcification levels and the size of the tonsilloliths [7]. In another study, Takahashi et al. [3] evaluated the prevalence and imaging characteristics of tonsilloliths by PR and CT images. Their study showed that the tonsilloliths were observed in $40.7 \%$ of CT images and the detection rate was $13.4 \%$ by PR. Thus, the rate of detection in PR was $32.8 \%$ compared with CT. In our study, the detection rate of $\mathrm{PR}$ was higher than in previous studies comparing the technique with CT $[3,7]$. Nevertheless, we found that the detection rate of tonsilloliths by PR was lower than that by CBCT. This result confirmed our hypothesis. The differences may be explained by soft tissue contrast and slice thickness between these imaging techniques [1].

The results of our study showed that the detection rate of PR increased as the size of the tonsilloliths increased. Tonsilloliths larger than $6 \mathrm{~mm}$ were detected by PR in a previous CT study [3]. Similarly, all the $5 \mathrm{~mm}$ or larger tonsilloliths were detected by PR in our study. Furthermore, as the number of tonsilloliths increased, the incidence of tonsilloliths increased in our study. The calcification degree, number, size, and localization of the tonsilloliths, and individual anatomical differences like bone density, may affect the detection of these calcifications on PR images [7].

\section{Conclusion}

The results of this study showed that more than half of the tonsilloliths observed on CBCT were also detected by PR. Tonsilloliths larger than $2 \mathrm{~mm}$ were more likely to be detected on PR images. 


\section{Statement of Ethics}

Ethical approval was received from Pamukkale University Ethics Committee (60116787-020/8903).

\section{Disclosure Statement}

All authors declare that they do not have any conflicts of interest.

\section{References}

1 White SC, Pharoah MJ. Oral Radiology, Principles and Interpretation. 7th ed. St. Louis: Mosby; 2014.

2 Misırlioglu M, Nalcaci R, Adisen MZ, Yardımci S. Bilateral and pseudobilateral tonsilloliths: three dimensional imaging with cone-beam computed tomography. Imaging Sci Dent. 2013 Sep;43(3):163-9.

3 Takahashi A, Sugawara C, Kudoh T, Ohe G, Takamaru N, Tamatani T, et al. Prevalence and imaging characteristics of palatine tonsilloliths evaluated on 2244 pairs of panoramic radiographs and CT images. Clin Oral Investig. 2017 Jan;21(1):85-91.

4 Babu B B, Tejasvi M L A, Avinash CK, B C. Tonsillolith: a panoramic radiograph presentation. J Clin Diagn Res. 2013 Oct;7(10): 2378-9.

5 Mesolella M, Cimmino M, Di Martino M, Criscuoli G, Albanese L, Galli V. Tonsillolith. Case report and review of the literature. Acta Otorhinolaryngol Ital. 2004 Oct;24(5):302-7.

6 Aoun G, Nasseh I, Diab HA, Bacho R. Palatine Tonsilloliths: A retrospective study on 500 digital panoramic radiographs. J Contemp Dent Pract. 2018 Oct;19(10):1284-7.

7 Oda M, Kito S, Tanaka T, Nishida I, Awano S, Fujita Y, et al. Prevalence and imaging characteristics of detectable tonsilloliths on 482 pairs of consecutive $\mathrm{CT}$ and panoramic radiographs. BMC Oral Health. 2013 Oct;13(1):54

8 Kim MJ, Kim JE, Huh KH, Yi WJ, Heo MS, Lee SS, et al. Multidetector computed tomography imaging characteristics of asymptomatic palatine tonsilloliths: a retrospective study on 3886 examinations. Oral Surg Oral Med Oral Pathol Oral Radiol. 2018 Jun; 125(6):693-8.

9 Thakur JS, Minhas RS, Thakur A, Sharma DR, Mohindroo NK. Giant tonsillolith causing odynophagia in a child: a rare case report. Cases J. 2008 Jul;1(1):50.

10 Kim KS. Referred otalgia induced by a large tonsillolith. Korean J Fam Med. 2013 May; 34(3):221-3.

11 Lo RH, Chang KP, Chu ST. Upper airway obstruction caused by bilateral giant tonsilloliths. J Chin Med Assoc. 2011 Jul;74(7):329_ 31.
12 Takahashi A, Sugawara C, Kudoh T, Uchida $D$, Tamatani T, Nagai H, et al. Prevalence and imaging characteristics of palatine tonsilloliths detected by CT in 2,873 consecutive patients. ScientificWorldJournal. 2014;2014: 940960.

13 Ram S, Siar CH, Ismail SM, Prepageran N Pseudo bilateral tonsilloliths: a case report and review of the literature. Oral Surg Oral Med Oral Pathol Oral Radiol Endod. 2004 Jul; 98(1):110-4.

14 Pauwels R, Beinsberger J, Stamatakis $H$, Tsiklakis $\mathrm{K}$, Walker A, Bosmans $\mathrm{H}$, et al.; SEDENTEXCT Project Consortium. Comparison of spatial and contrast resolution for cone-beam computed tomography scanners. Oral Surg Oral Med Oral Pathol Oral Radiol. 2012 Jul;114(1):127-35.

15 Moshfeghi M, Navabi SS, Soltani P, Moaddabi A. Prevalence of tonsillolith on cone beam computed tomography images in patients attending Shahid Beheshti University of Medical Sciences. Br J Med Med Res. 2017;19(11): $1-6$.

16 Demiralp K, Bayrak S, Kursun Cakmak E. Prevalence and characteristics of palatine tonsilloliths in cone beam computed tomography images: a retrospective study. KU Tip Fak Derg. 2017;19:97-102.

17 Ozdede M, Kayadugun A, Ucok O, Altunkaynak B, Peker I. The assessment of maxillofacial soft tissue and intracranial calcifications via cone-beam computed tomography. Curr Med Imaging Rev. 2018;14(5):798-806.

18 Schwarz D, Kabbasch C, Scheer M, Mikolajczak S, Beutner D, Luers JC. Comparative analysis of sialendoscopy, sonography, and CBCT in the detection of sialolithiasis. Laryngoscope. 2015 May; 125(5):1098-101.

19 Cho W, Park H. Transoral sonographic diagnosis of tonsilloliths: report of 3 cases. J Ultrasound Med. 2013 Nov;32(11):2037-42.

20 Sutter W, Berger S, Meier M, Kropp A, Kielbassa AM, Turhani D. Cross-sectional study on the prevalence of carotid artery calcifications, tonsilloliths, calcified submandibular lymph nodes, sialoliths of the submandibular gland, and idiopathic osteosclerosis using digital panoramic radiography in a Lower Austrian subpopulation. Quintessence Int. 2018 Jan;22:231-42.
21 Bamgbose BO, Ruprecht A, Hellstein J, Timmons S, Qian F. The prevalence of tonsilloliths and other soft tissue calcifications in patients attending oral and maxillofacial radiology clinic of the university of iowa. ISRN Dent. 2014 Jan;2014:839635.

22 Aspestrand F, Kolbenstvedt A. Calcifications of the palatine tonsillary region: CT demonstration. Radiology. 1987 Nov;165(2):479-80.

23 Fauroux MA, Mas C, Tramini P, Torres JH Prevalence of palatine tonsilloliths: a retrospective study on 150 consecutive CT examinations. Dentomaxillofac Radiol. 2013;42(7): 20120429.

24 Ergun T, Lakadamyali $\mathrm{H}$. The prevalence and clinical importance of incidental soft-tissue findings in cervical CT scans of trauma population. Dentomaxillofac Radiol. 2013;42(10): 20130216.

25 Pette GA, Norkin FJ, Ganeles J, Hardigan P, Lask E, Zfaz S, et al. Incidental findings from a retrospective study of 318 cone beam computed tomography consultation reports. Int $J$ Oral Maxillofac Implants. 2012 May-Jun; 27(3):595-603.

26 Price JB, Thaw KL, Tyndall DA, Ludlow JB, Padilla RJ. Incidental findings from cone beam computed tomography of the maxillofacial region: a descriptive retrospective study. Clin Oral Implants Res. 2012 Nov; 23(11):1261-8.

27 Allareddy V, Vincent SD, Hellstein JW, Qian F, Smoker WR, Ruprecht A. Incidental findings on cone beam computed tomography images. Int J Dent. 2012;2012:871532.

28 Pruet CW, Duplan DA. Tonsil concretions and tonsilloliths. Otolaryngol Clin North Am. 1987 May;20(2):305-9.

29 Ozcan E, Ural A, Oktemer TK, Alpaslan G. Bilateral tonsillolithiasis: a case report. Oral Surg Oral Med Oral Pathol Oral Radiol Endod. 2006 Sep;102(3):e17-8.

30 Ghabanchi J, Haghnegahdar A, Khojastehpour L, Ebrahimi A. Frequency of tonsilloliths in panoramic views of a selected population in southern iran. J Dent (Shiraz). 2015 Jun;16(2):75-80 